\title{
Konferencja przekładoznawcza Norma a uzus III. Przekład specjalistyczny jako dylemat, Wydział Neofilologii UAM, Poznań 11-12.01.2018 r. (sprawozdanie)
}

DOI: http://dx.doi.org/10.12775/RP.2018.021

W dniach 11-12 stycznia 2018 r. odbyła się w Poznaniu na Wydziale Neofilologicznym trzecia konferencja przekładoznawcza z cyklu Norma a uzus. Inspiratorką tych naukowych spotkań, prowadzonych głównie z udziałem romanistów, germanistów i anglistów, jest romanistka Barbara Walkiewicz. Instytucjonalnie patronat nad tym wydarzeniem objęła Teresa Tomaszkiewicz, reprezentująca międzywydziałowe studia tłumaczeniowe, oraz Instytut Germanistyki w osobie Beate Sommerfeld. Wielkim atutem sesji był brak bardzo często spotykanego na innych konferencjach podziału na sekcje, dzięki czemu każdy z uczestników miał szansę wysłuchać wszystkich wygłoszonych referatów. Zarówno w pierwszym, jak i drugim dniu konferencji referowało dziewięć osób, a każdorazowo pierwsze $\mathrm{z}$ wystąpień miało formę wykładu plenarnego. Pod względem liczby wystąpień konferencję można więc zaliczyć do stosunkowo małych. Na szczęście nie wielkość, a jakość jest miernikiem tego typu przedsięwzięć, a w tym wypadku i podejmowana tematyka, i wnikliwa, drobiazgowa dyskusja świadczą jednoznacznie na korzyść organizatorów.

Po oficjalnym otwarciu konferencji przez prodziekana ds. nauki Wydziału Neofilologii Macieja Karpińskiego oraz wspomniane wyżej osoby (Tomaszkiewicz, Sommerfeld) wystąpił Piotr Mamet z wykładem na temat dylematów tłumacza w procesie przekładu humoru, a konkretnie gier słownych w dwóch typach tłumaczeń audiowizualnych (napisy, lektor) na język polski. Wychodząc od teorii humoru, $w$ tym przede wszystkim teorii bisocjacji, Manet zwrócił uwagę na dużą trudność w znalezieniu takich rozwiązań w tłumaczeniach, aby wybrane środki leksykalne realizowały oba rejestry, budujące efekt humoru w języku oryginału. Dyskusja po wystąpieniu oraz jej kontynuacja w kuluarach była zapowiedzią gorących obrad.

Drugie wystąpienie dotyczyło dylematów nauczyciela akademickiego kierującego seminarium magisterskim $\mathrm{w}$ ramach studiów tłumaczeniowych. W nim Teresa Tomaszkiewicz zaakcentowała, że mimo wspólnych celów w zakresie kształcenia tłumaczy i podobnych standardów jakości, 
realizowanych w ramach EMT (Europaen Masterr's in Translation), seminarium magisterskie w uczelniach różnych krajów należących do EMT ma najbardziej zróżnicowany charakter, począwszy od liczby punktów ECTS (od 2 do 38 \% punktów), przez czas jego trwania (od roku do dwóch), na określeniu jego istoty kończąc. Tomaszkiewicz zwróciła uwagę również na opracowywanie nowego zestawu kompetencji tłumacza, w których dużą większą rolę niż dotychczas odgrywać mają kompetencje związane z rozwojem technologicznym. Autorka zaznaczyła, że duża część kompetencji szczegółowych może być $\mathrm{z}$ powodzeniem realizowana $\mathrm{w}$ ramach seminarium magisterskiego.

W kolejnym wystąpieniu przedstawiono ciekawy projekt badań empirycznych, którego celem jest ustalenie, czy przekład na język obcy przez profesjonalnych tłumaczy jest procesem bardziej złożonym i czasochłonnym niż tłumaczenie na język ojczysty, czy mówiąc inaczej, jaki jest wpływ kierunku tłumaczenia na jego przebieg i jakość. Badania prowadzi grupa pod kierunkiem Barbary Whyatt, a projekt oprócz wymienionej prezentował też jej doktorant Tomasz Kościuczuk. W badaniach wykorzystuje się analizę całkowitej aktywności na komputerze (key-logging), obserwacje ruchów gałki ocznej (eye-tracing) oraz monitorowanie ekranu komputera. Poza tym zespół badawczy dysponuje również ankietami oraz zleca profesjonalną korektę tłumaczeń, by w ten sposób ocenić ich jakość. Wystąpienie potwierdza w całej rozciągłości postępujący proces włączania metod empirycznych do badań przekładoznawczych w Polsce. Prowadzone badania mają szansę zweryfikować powtarzane $\mathrm{w}$ tym zakresie wyobrażenie, niepoparte dotychczas miarodajnymi informacjami, wedle którego tłumaczenie na język ojczysty jest procesem prostszym i łatwiejszym.

W następnym wystąpieniu Małgorzata Jokiel podjęła temat dydaktyki przekładu specjalistycznego ustnego wobec jakości i oczekiwań rynku. Referentka skupiła się na dydaktyce w zakresie dwóch typów tłumaczeń: a vista i konsekutywnym i podzieliła się swoimi doświadczeniami w pracy ze studentami.

Mieczysław Nasiadka przedstawił wpływ decyzji tłumacza ustnego w kontekście funkcji przekładu i jego odbioru. Referent trochę zbyt długo prezentował ważne i zasadne kwestie dotyczące teorii komunikacji, więc na wnikliwe przedstawienie tematu nie starczyło czasu. Niemniej dyskusja po wystąpieniu uświadamia w całej rozciągłości wagę zagadnienia i konieczność prowadzenia systematycznych badań w tym zakresie.

Ostatnim wystąpieniem przed przerwą na kawę był referat Katarzyny Krajewskiej na temat relacji między tłumaczeniem biznesowym a środowi- 
skowym oraz statusu i roli tłumacza. Referentka jest od lat praktykującym tłumaczem, więc poruszony problem, w szczególności w odniesieniu do roli tłumacza, przedstawiła z perspektywy wykonywanego przez siebie zawodu. Rozważania wstępne nie wniosły może wiele nowego, jednak po raz kolejny uświadomiły wielką trudność, jaką sprawia stworzenie typologii obejmującej wszystkie rodzaje tłumaczeń w oparciu o spójne kryteria.

Po przerwie bardzo ciekawy referat wygłosiła Beate Sommerfeld, koncentrując się na ilustracjach książek dla dzieci jako źródle dylematów tłumacza. Przedmiotem analizy były trzy przekłady książki Mały książę Antoine de Saint-Exupery’ego na język niemiecki. Referentka pokreśliła, że ilustracje stanowią integralną część przekładu, a ich odpowiednie uwzględnienie ma wpływ na odbiór książki.

Małgorzata Czubińska przedstawiła analizę sposobów wykorzystania napisów scenicznych w przekładzie sztuk teatralnych na przykładzie Malta Festival Poznań 2017. Tym samym uświadomiła uczestnikom, że przekład audiowizualny wchodzi w obszary wychodzące daleko poza film i że w tych obszarach podlega procesowi standaryzacji.

$\mathrm{W}$ ostatnim wystąpieniu pierwszego dnia konferencji w problematykę tłumaczenia terminologii muzycznej z języka tureckiego wprowadziła uczestników Agata Pawlina. Referentka podkreśliła diametralnie inne tradycje muzyki tureckiej, sprawiające bardzo ograniczone możliwości oddania terminów tureckich terminami zakorzenionymi w kulturze polskiej czy szerzej w cywilizacji zachodniej. W związku z powyższym właściwym rozwiązaniem w większości przypadków wydaje się przenoszenie terminów tureckich na grunt polski z odpowiednim opisowym ich wyjaśnianiem.

W drugim dniu konferencji rola budzika przypadła Lechowi Zielińskiemu, który wygłosił wykład na temat: Między normą (prawną) a racjonalnym działaniem. Wybrane dylematy pracy tłumacza przysięgłego na rzecz organów ścigania.

Po długiej dyskusji głos zabrała Karolina Kęsicka, zastanawiając się nad pytaniem, czy precyzja w przekładzie jest paradygmatem czy utopią. Referentka podjęła problem przekładu dwóch pojęć opisujących podejrzenie popełnienia przestępstwa w języku niemieckim, mianowicie pojęć dringender Tatverdacht oraz hinreichender Tatverdacht, a następnie poszukiwała sposobu ich oddania w języku polskim i w systemie polskiego prawa karnego. W dyskusji podkreślono, że należy te dwa pojęcia rozpatrywać łącznie z trzecim (Anfangsverdacht), by zagadnienie ująć w całości.

W kolejnym wystąpieniu Barbara Walkiewicz dokonała oceny jakości tłumaczeń wykonanych przez profesjonalne biura tłumaczeń. Chodzi- 
ło o opisy typów mieszkań i domów występujące w ofertach handlowych. Referentka swoje rozważania zilustrowała zdjęciami i schematami, dzięki którym uświadomiła, jak różne wyobrażenia w porównaniu do wyobrażeń generowanych określeniami $\mathrm{w}$ języku wyjściowym występują u odbiorcy tłumaczenia.

Przed ostatnią przerwą wystąpiły jeszcze Beata Springer (problematyka mianownictwa medycznego i jego konsekwencje w tłumaczeniu tekstów specjalistycznych) i Olga Witczak (uzus w tłumaczeniu wspomaganym komputerowo). Druga z wymienionych prelegentek omówiła wyniki przeprowadzonych badań nad upodobaniami technologicznymi tłumaczy.

W ostatniej sesji wygłoszono cztery referaty. Patrycja Bobowska-Nastarzewska mówiła o roli tłumacza pisemnych tekstów specjalistycznych na podstawie własnych doświadczeń traduktologicznych. W dyskusji podkreślono, że tłumaczenie tekstów filozoficznych, bo o takich była mowa, to raczej obszar tekstów naukowych, w mniejszym stopniu specjalistycznych. Zresztą i w tym wypadku widać jak na dłoni problem typologii tłumaczeń, o którym wspomniano wcześniej.

Patrycja Masłowska zwróciła uwagę na organizację „Tłumacze bez granic" świadczącą bezpłatną pomoc w zakresie usług tłumaczeniowych. Skupiła się ona na roli tłumacza we współczesnym świecie. Referat ciekawy, choć w dyskusji podkreślono konieczność dalszych badań w celu sprawdzenia, czy głoszone przez organizację postulaty i tworzone bazy danych rzeczywiście odpowiadają stanowi faktycznemu.

Damian Wątrobiński poruszył mało rozeznany temat roli audiodyskryptora i jego dylematów w procesie przekładu audiowizualnego. Podkreślić należy, że przekład audiowizualny doczekał się w Polsce przynajmniej kilku publikacji, ale przedmiotem analizy referenta była audiodyskrypcja obrazów, a ten obszar na gruncie nauki polskiej pozostaje prawie nierozpoznany.

Ostatnia referentka Agnieszka Kaliska przedstawiła opracowaną przez siebie słowosieć polskich i francuskich wykładników technik wędkarskich.

Podsumowując, należy stwierdzić, że konferencja przekładoznawcza Norma a uzus III. Przekład specjalistyczny jako dylemat to konferencja stosunkowo mała z wyraźną dominacją przedstawicieli Uniwersytetu Adama Mickiewicza. Mimo tej dominacji uznać należy, że miała ona charakter ogólnopolski, gdyż referenci $z$ innych polskich ośrodków akademickich (Uniwersytet Warszawski, Uniwersytet Opolski, Akademia im. Jana Długosza w Częstochowie, Uniwersytet Jagielloński, Uniwersytet Mikołaja Kopernika w Toruniu) zarówno na poziomie wystąpień, jak i prowadzonej dyskusji 
wyraźnie podkreślali swoją obecność. Podejmowana tematyka była ciekawa i ważna, a wystąpienia dobrze przemyślane. Uważam konferencję za udaną i z przyjemnością wezmę udział w kolejnej edycji. Organizatorom można jedynie radzić, by zmniejszyli dominację własnego ośrodka.

Lech Zieliński

Lech.Zielinski@umk.pl

(Uniwersytet Mikołaja Kopernika w Toruniu)

(c) (1) $\Theta$ 